\title{
Antimalarial Activity of Solvent Fractions of the Stem Bark of Periploca linearifolia Quart.-Dill. \& A.Rich. (Asclepiadaceae) Against Plasmodium berghei in Mice
}

\author{
Wubetu Yihunie Belay ${ }^{\prime}$ \\ Abyot Endale Gurmu (D) ${ }^{2}$ \\ Zewdu Birhanu Wubneh (iD) ${ }^{3}$ \\ 'Department of Pharmacy, College of \\ Health Sciences, Debre Markos \\ University, Debre Markos, Ethiopia; \\ ${ }^{2}$ Department of Pharmacognosy, School \\ of Pharmacy, College of Medicine and \\ Health Sciences, University of Gondar, \\ Gondar, Ethiopia; ${ }^{3}$ Department of \\ Pharmacology, School of Pharmacy, \\ College of Medicine and Health Sciences, \\ University of Gondar, Gondar, Ethiopia
}

Correspondence: Wubetu Yihunie Belay Department of Pharmacy, College of Health Sciences, Debre Markos University Tel +2519101I2391

Email wubetuyihunie@gmail.com
Background: Currently, malaria elimination is intimidated by the emergence of antimalarial drug and insecticide resistance. This scenario urges scientists to develop new antimalarial drugs, where plant-based compounds are the major candidates.

Objective: The objective of this experiment was to examine the antimalarial activities of the solvent fractions of the stem bark of $P$. linearifolia in mice.

Methods: The dried hydromethanolic extract was treated with n-hexane, chloroform, and ethyl acetate solvents based on increasing order of polarity. For the suppressive test, after three hours post-inoculation of $P$. berghei, the first group was administered the vehicle $2 \mathrm{~mL} / 100 \mathrm{~g}$. The second group was given chloroquine $25 \mathrm{mg} / \mathrm{kg}$, whereas the remaining nine groups were administered 100 , 200 , and $400 \mathrm{mg} / \mathrm{kg}$ of each of the chloroform, ethyl acetate and aqueous fractions. Furthermore, the aqueous fraction was evaluated using Rane's model for the curative test. The result was statistically analyzed using a one-way analysis of variance (ANOVA). The results were considered significant at $\mathrm{P}<0.05$.

Results: In the suppressive test, the solvent fractions suppressed parasitemia level significantly ( $\mathrm{P}<0.01$ for $100 \mathrm{mg} / \mathrm{kg}, \mathrm{P}<0.001$ for 200 and $400 \mathrm{mg} / \mathrm{kg}$ of the aqueous and $\mathrm{P}<0.01$ for $200 \mathrm{mg} / \mathrm{kg}, \mathrm{P}<0.001$ for $400 \mathrm{mg} / \mathrm{kg}$ of chloroform fractions) as compared to vehicle-treated mice, whereas in the curative model $400 \mathrm{mg} / \mathrm{kg}$ of the aqueous fraction $(\mathrm{P}<0.01)$ showed a significant parasitemia level reduction.

Conclusion: The results of this study indicated that the solvent fractions have promising antiplasmodial activity against Plasmodium berghei, which is consistent with the earlier in vivo study of the hydromethanolic extract.

Keywords: antimalarial, Plasmodium berghei, Periploca linearifolia, solvent fractions

\section{Background}

Malaria claimed over 409,000 lives globally in the year 2019. Moreover, the majority of the cases and deaths occur in the WHO African Region. ${ }^{1}$ From the five Plasmodium $(P)$ species, ie, $P$. falciparum, $P$. vivax, $P$. malariae, $P$. ovale, and $P$. knowlesi, which cause human malaria, $P$. falciparum is the deadliest; despite, $P$. vivax covers a much wider area of distribution. $^{2-4}$ Currently, available antimalarials fall into three broad categories according to their chemical structure and mode of action. These are aryl amino alcohol compounds: quinine, quinidine, chloroquine, amodiaquine, mefloquine, halofantrine, lumefantrine, piperaquine, tafenoquine; antifolate compounds: pyrimethamine, proguanil, chlorproguanil, trimethoprim; and artemisinin compounds (artemisinin, dihydroartemisinin, artemether, artesunate). ${ }^{5}$ After finding favorable safety and efficacy profiles from 
RTS, S malaria vaccine pilot program in Ghana, Kenya, and Malawi, WHO recommends widespread use of the RTS, S/ AS01 (RTS, S) malaria vaccine among children in sub-Saharan Africa and other regions with moderate to high P. falciparum malaria transmission. ${ }^{6}$

Periploca linearifolia ( $P$. linearifolia), Asclepiadaceae, is a liana, woody at base, up to $10 \mathrm{~m}$ long, glabrous, and latex copious. ${ }^{7}$ Hot water decoction of root bark of P. linearifolia is used as antimalarial in Meru District, Kenya. ${ }^{8}$ An in vitro study in Kenya on methanolic and chloroform extracts of the stem bark of $P$. linearifolia showed a promising antimalarial activity. ${ }^{9}$ Moreover, hydromethanolic extract of stem bark of $P$. linearifolia showed significant antimalarial activity in early and established Plasmodium infection in mice. In addition, the stem bark of $P$. linearifolia is used for the treatment of malaria by the local community in North West Ethiopia. ${ }^{10}$

Nowadays, malaria elimination is intimidated by the development of mosquito resistance to insecticides and antimalarial drug resistance. ${ }^{1}$ Scientists fear this may lead us to the pre-antimicrobial era. Hence, to solve this problem, there exists a high interest in developing new antimalarial drugs. Plants become a source of different drugs including antimalarial lead compounds and drug candidates like quinine from cinchona bark ${ }^{11}$ and artemisinins from Artemisia annua. ${ }^{12}$ Therefore, based on the previous study on the hydromethanolic extract, ${ }^{10}$ the present study aimed to identify which solvent fraction/s has/have antimalarial activities and compare their antimalarial activities in Plasmodium berghei infected mice. Such types of preliminary phytochemical tests in laboratory animals are initial steps in the drug discovery and development process. Therefore, the present study could be regarded as an important step in finding new antimalarial lead compounds which will address the emergence of antimalarial drug resistance.

\section{Methods}

\section{Collection and Preparation of Plant Materials}

The plant $P$. linearifolia, a wild plant, was collected from Lay Armachiho Woreda, $23 \mathrm{~km}$ north of Gondar city in December 2016 by negotiating with the local community. Permission and negotiation with the local community to collect the plant was arranged by the Traditional Medicine Research Project, University of Gondar (under the mega project of the university with a reference number of VP/RCS/05/ $445 / 2015)$. The plant was covered with plastic sheets during transportation. The plant was identified as Periploca linearifolia Quart.-Dill. and A.Rich. by a botanist and a voucher specimen was deposited (No. WY001) at the Herbarium, College of Natural Sciences, University of Gondar for future reference. The stem bark was peeled from the plant, air-dried at room temperature under shade and reduced to the appropriate size.

\section{Animals Used}

Healthy, adult Swiss albino mice of either sex (22-32 g, and 6-8 weeks of age) were obtained from the Ethiopian Public Health Institute, Addis Ababa. The animals were housed in cages under standard conditions and provided with a pellet diet and water ad libitum. The animals were allowed to attune to the laboratory condition for a week before beginning the experiment. All protocols were followed based on the international animal care and welfare guidelines. ${ }^{13}$

\section{Parasites Inoculation}

Chloroquine sensitive strain of $P$. berghei (ANKA strain) obtained from the Ethiopian Public Health Institute (EPHI), Addis Ababa was used. The parasites were maintained by serial passage of blood from infected mice to non-infected ones on weekly basis.

\section{Drugs, Reagents, and Instruments}

Normal isotonic saline (Euro-med Laboratories, Philippines), n-hexane, $2 \%$ tween 80 , ethyl acetate (Loba chemicals, India), chloroform (Atico, India), citrate dextrose (Deluxe Scientific Surgico, India), Giemsa (Science Lab, USA), ethanol (Nice chemicals, India), Electrical balance, $1 \mathrm{~mL}$ syringes, needles, vials, examination glove, permanent marker, Whatman filters paper No.1 (Whatman ${ }^{\circledR}$, England), collecting flask, separatory funnel, hematocrit centrifuge, Micro-Hematocrit Reader, microscope, laboratory glasswares, and lyophilizer (Labfreez, China) were used.

\section{Preparation of Fraction}

The hydromethanolic extract was prepared ${ }^{10}$ and subjected to fractionation using n-hexane, chloroform and ethyl acetate. One hundred thirty gram of $80 \%$ hydromethanolic extract was suspended in a separatory funnel in $400 \mathrm{~mL}$ of distilled water and partitioned with $3 \times 400 \mathrm{~mL}$ n-hexane. The filtrate was transferred into a beaker and put in an oven with a temperature adjusted at $40^{\circ} \mathrm{C}$ to obtain the $\mathrm{n}$-hexane fraction. The aqueous residue was then partitioned with $3 \times 400 \mathrm{~mL}$ chloroform. The chloroform filtrate was concentrated similarly as n-hexane fraction to have 
chloroform fraction. Similarly, the remaining residue was partitioned with $3 \times 400 \mathrm{~mL}$ ethyl acetate. Then the filtrate was concentrated to get ethyl acetate fraction. The remaining residue, i.e the aqueous fraction, was transferred in a wide beaker for drying. The hexane, chloroform and ethyl acetate fractions were concentrated and dried in an oven under $40^{\circ} \mathrm{C}$. Whereas the aqueous fraction was dried by lyophilizer (Labfreez, China). Finally, all the dried fractions were then transferred into separate vials and stored in a refrigerator at $-4^{\circ} \mathrm{C}$ for further use.

\section{In vivo Antimalarial Tests Parasite Inoculation}

Swiss Albino mice previously infected with $P$. berghei and having parasitemia levels of $20-30 \%$ were used as donors. The donor mice were then sacrificed by decapitation and blood was collected by cardiac puncture into a heparinized capillary tube containing $0.5 \%$ trisodium citrate. The blood was then diluted with physiological saline $(0.9 \%)$ based on the parasitemia level of the donor mice and the red blood cell (RBC) count of normal mice, ${ }^{14}$ in such a way that $1 \mathrm{~mL}$ blood contains $5 \times 10^{7}$ infected RBCs. Each mouse was then given $0.2 \mathrm{~mL}$ of this diluted blood intraperitoneally, which contained $1 \times 10^{7} P$. berghei infected RBCs.

\section{Grouping and Dosing of Animals}

Infected mice were randomly divided into eleven groups of five mice per group. GroupI-IX were treated with the aqueous, ethyl acetate, and chloroform fractions each at 100,200 , and $400 \mathrm{mg} / \mathrm{kg}$, orally once daily, respectively. The remaining two groups served as negative and positive controls and administered 2\% Tween $80(2 \mathrm{~mL} / 100 \mathrm{~g})^{15}$ and chloroquine $25 \mathrm{mg} / \mathrm{kg}$, orally once daily, respectively.

\section{The Four-Day Suppressive Test}

The standard four-day suppressive test method was used. ${ }^{16,17}$ Treatment was started 3 hours post-infection on day 0 and continued once daily for four days (ie, from day 0 to day 3). On the fifth day (D4) thin smears of blood films were obtained from the peripheral blood on the tail of each mouse. The smears were placed on microscopic slides which were fixed with methanol and stained with $10 \%$ Giemsa at $\mathrm{pH} 7.2$ for $15 \mathrm{~min}$. The parasitemia level was determined by counting the number of parasitized erythrocytes out of four random fields of the microscope. Average percent parasitemia and suppression were calculated by using the following formula. ${ }^{16,17}$

$$
\begin{gathered}
\% \text { Parasitemia }=\frac{\text { Number of parasitized } \mathrm{RBC}}{\text { Total number of } \mathrm{RBC}} \times 100 \\
\% \text { suppression }=\frac{\text { mean parasitemia of negative control }}{\text { mean parasitemia of negative control }} \times 100
\end{gathered}
$$

\section{Curative Test}

Evaluation of the curative potential of the solvent fractions was carried out according to the method described by Ryley and Peters. ${ }^{18}$ On Day 0, standard inocula of $1 \times 10^{7}$ infected erythrocytes were inoculated in mice intraperitoneally. Seventy-two hours later, mice were randomly divided into their respective groups and dosed accordingly once daily for five days. Giemsa stained thin blood film was prepared from the tail of each mouse daily for 5 days to monitor parasitemia levels.

\section{Mean Survival Time (MST)}

MST was determined arithmetically by calculating the average survival time (days) of mice starting from the date of infection over 30 days (D0-D29).

$$
\text { MST }=\frac{\text { Sum of survival time of all mice in agroup (days) }}{\text { Total number of mice in that group }}
$$

\section{Packed Cell Volume Measurement}

Packed cell volume (PCV) was taken to predict the effectiveness of the solvent fractions in averting the destruction of RBCs associated with the escalation of the malaria parasite. Heparinized capillary tubes were used for the collection of blood from the tail of each mouse. The capillary tubes were filled with blood up to $3 / 4$ th of their volume and were sealed at the dry end with sealing clay. The tubes were then placed in a micro-hematocrit centrifuge, with the sealed end outwards, and were centrifuged for $5 \mathrm{~min}$ at 11,000 revolutions per minute (rpm). The tubes were then taken out of the centrifuge and PCV was determined using a standard Micro-Hematocrit Reader. PCV is a measure of the proportion of RBCs to plasma and measured before inoculating the parasite and at day four using the following relationship:

PCV $=\frac{\text { The volume of erythrocytes in a given volume of blood }}{\text { Total blood volume }} \times 100 \%$ 


\section{Monitoring of Body Weight and Temperature Changes}

For a four-day suppressive test and Rane's test of the solvent fractions, mice were weighed to observe whether the stem bark solvent fractions prevented weight loss. Weights were taken on the first day (D0) and day five (D4). Rectal temperature was measured by a digital thermometer before infection, four hours after infection, and then daily. For Rane's test, body weight and temperature were measured before infection and from day 3-7 after infection.

\section{Ethical Considerations}

Before the beginning of the experiment, the proposal was evaluated, approved and ethical approval for this study was obtained from the Ethical Review Committee of School of Pharmacy, University of Gondar (ethical approval number, SOP4/75/09). At the end of the experiment, infected mice were euthanized by hypoxia (by exposing the mice to a high concentration of $\mathrm{CO}_{2}$ ) which makes them unconscious before death. After death is verified, disposal of euthanized laboratory animals is conducted consistent with health and environmental concerns.

\section{Statistical Analysis}

The raw data obtained from the experiments were expressed as mean \pm SEM (standard error of the mean). Statistical analyses were carried out by using SPSS Statistical software version 20. Parasitemia level, \% suppression, mean survival time, PCV, temperature, and weight were statistically analyzed using one-way analysis of variance (ANOVA) followed by post hoc Tukey's Multiple Comparison Test. The results were considered significantly different when $\mathrm{p}<0.05$.

\section{Data Quality Control}

Randomization was used during the grouping of experimental animals and assignments of treatments. Besides, all mice were coded with different colors on their tails. Furthermore, codes were utilized for all microscopic slides. Finally, parasitized RBCs were counted blindly by a medical laboratory technician.

\section{Result}

\section{Percentage Yields of Solvent Fractions}

From $130 \mathrm{~g}$ of the $80 \%$ methanolic extract of stem bark of P. linearifolia, ${ }^{10}$ n-hexane $(0.15 \%)$ and the chloroform
$(2.85 \%)$ fractions were found to be greenish whereas, the dark reddish for ethyl acetate (4\%) and reddish color for an aqueous fraction (93\%) were found. The n-hexane fraction was not considered in the experiment due to insufficient quantity.

\section{Antimalarial Activity}

Suppressive Test of the Solvent Fractions

All the three doses of the aqueous fractions reduced parasitemia level compared to the vehicle-treated group $(\mathrm{p}<0.01$ for $100 ; \mathrm{p}<0.001$ for 200 and $400 \mathrm{mg} / \mathrm{kg}$ ), although the extent of reduction was less than that of chloroquine $25 \mathrm{mg} /$ $\mathrm{kg}$, which produced $100 \%$ suppression (Table 1). Both 200 and $400 \mathrm{mg} / \mathrm{kg}$ of the chloroform fractions showed a significant parasitemia level reduction compared to vehicle-treated group ( $\mathrm{p}<0.01$ for $200 \mathrm{mg} / \mathrm{kg}$; $\mathrm{p}<0.001$ for $400 \mathrm{mg} / \mathrm{kg}$ ). However, only $400 \mathrm{mg} / \mathrm{kg}$ of ethyl acetate fraction reduced parasitemia level significantly $(p<0.05)$. The rank order of chemosuppression of the solvent fractions was aqueous $(53.4 \%)>$ chloroform $(41.11 \%)>$ ethyl acetate $(35.51 \%)$, at the dose of $400 \mathrm{mg} / \mathrm{kg}$. Survival time was significantly prolonged by $400 \mathrm{mg} / \mathrm{kg}$ of all three fractions as compared to vehicle-treated mice $(\mathrm{p}<0.05)$ (Table 1$)$.

Effect of Solvent Fractions on Rectal Temperature, Body Weight, and Packed Cell Volume on the Four-Day Suppressive Test

All doses of the fractions, except $400 \mathrm{mg} / \mathrm{kg}$ chloroform extract failed to prevent body weight reduction significantly. But, $400 \mathrm{mg} / \mathrm{kg}$ of chloroform showed a significant attenuation of bodyweight reduction $(\mathrm{p}<0.05)$ (Table 2$)$. Moreover, all doses of the aqueous fraction significantly $(\mathrm{p}<0.001)$ prevented the rectal temperature reduction caused by escalating parasitemia and the effect was comparable to that observed with chloroquine $25 \mathrm{mg} / \mathrm{kg}$. Similarly, all doses of chloroform fraction ( $\mathrm{p}<0.01), 200$ and $400 \mathrm{mg} / \mathrm{kg}$ of ethyl acetate fraction $(\mathrm{p}<0.05)$ significantly prevented rectal temperature reduction (Table 2).

Analysis of rectal temperature change within groups indicated that mice administered with $100 \mathrm{mg} / \mathrm{kg}$ and $400 \mathrm{mg} / \mathrm{kg}$ of the aqueous fraction did not show any significant temperature change after treatment. Similarly, ethyl acetate and chloroform fractions did not show any significant prevention of temperature change. On the other hand, chloroquine $25 \mathrm{mg} / \mathrm{kg}$ prevented a significant rectal temperature and weight change (Table 2).

$\mathrm{PCV}$ reduction was significantly attenuated by $400 \mathrm{mg} / \mathrm{kg}$ chloroform fraction ( $\mathrm{p}<0.01$ ). Also, 200 and $400 \mathrm{mg} / \mathrm{kg}$ of 
Table I Parasitemia Level and Survival Time of Infected Mice Treated Solvent Fractions of $P$. linearifolia in the 4-Day Suppressive Test

\begin{tabular}{|c|c|c|c|c|}
\hline Extract/Fraction & Dose/(Mg/Kg) & $\begin{array}{l}\text { Parasitaemia Level/Number } \\
\text { of Parasitized RBCs }\end{array}$ & \% Suppression & Survival Time/Days \\
\hline \multirow[t]{3}{*}{ Aqueous fraction } & 100 & $25.29 \pm 3.23^{\mathrm{a} * *}, \mathrm{~b} * * *$ & 39.06 & $8.40 \pm 0.5^{\mathrm{b} * * *}$ \\
\hline & 200 & $22.69 \pm 3.22^{\mathrm{a} * * *}, \mathrm{~b} * * *$ & 45.37 & $9.80 \pm 1.06^{\mathrm{b} * * *}$ \\
\hline & 400 & $19.34 \pm 2.13^{\mathrm{a} * * *}, \mathrm{~b} * * *$ & 53.40 & $15.80 \pm 3.92^{\mathrm{a} *}, \mathrm{~b}_{* * *}$ \\
\hline \multirow[t]{3}{*}{ Ethyl acetate fraction } & 100 & $34.87 \pm 3.94^{\mathrm{b}} * * *$ & 15.99 & $8.40 \pm 0.74^{\mathrm{b} * * *}$ \\
\hline & 200 & $33.72 \pm 4.40^{\mathrm{b}} * * *$ & 20.70 & $10.40 \pm 0.92^{\mathrm{b} * * *}$ \\
\hline & 400 & $26.77 \pm 2.29^{\mathrm{a} *}, \mathrm{~b} * * *$ & $35.5 \mathrm{I}$ & $10.80 \pm 1.39^{\mathrm{a} *}, \mathrm{~b} * * *$ \\
\hline \multirow[t]{3}{*}{ Chloroform fraction } & 100 & $31.24 \pm 2.57^{\mathrm{b} * * *}$ & 24.74 & $8.40 \pm 1.14^{\mathrm{b} * * *}$ \\
\hline & 200 & $26.98 \pm 3.01^{\mathrm{a} * *}, \mathrm{~b} * * *$ & 35.00 & $10.00 \pm 1.58^{\mathrm{b} * * *}$ \\
\hline & 400 & $24.44 \pm 2.89^{\mathrm{a} * * *}, \mathrm{~b} * * *$ & 41.11 & $\mid 4.00 \pm 5.00^{\mathrm{a} * *}, \mathrm{~b} * * *, \mathrm{c} *$ \\
\hline $2 \%$ Tween 80 & 10 & $41.52 \pm 2.81$ & - & $7.00 \pm 0.31$ \\
\hline Chloroquine & 25 & $0.00 \pm 0.00^{\mathrm{a}} * * *$ & 100.00 & $30.00 \pm 0.00^{\mathrm{a} * * *}$ \\
\hline
\end{tabular}

Notes: Data are expressed as mean \pm SEM; $n=5$; ${ }^{a}$ compared to vehicle (2\%Tween $802 \mathrm{~mL} / 100 \mathrm{~g}$ for fractions); ${ }^{b}$ compared to chloroquine $25 \mathrm{mg} / \mathrm{kg}$; 'compared to chloroform fraction $100 \mathrm{mg} / \mathrm{kg}:{ }^{*} \mathrm{p}<0.05, * * \mathrm{p}<0.01$, ***p $<0.001$.

Table 2 Rectal Temperature, Body Weight, and Packed Cell Volume Change of Infected Animals Treated with Solvent Fractions of P. linearifolia in the 4-Day Suppressive Test

\begin{tabular}{|c|c|c|c|c|c|c|c|c|c|}
\hline \multirow[t]{2}{*}{ Dose } & \multicolumn{3}{|c|}{ Temperature $/{ }^{\circ} \mathrm{C}$} & \multicolumn{3}{|c|}{ Weight/Gram } & \multicolumn{3}{|c|}{ PCV } \\
\hline & Do & D4 & $\%$ Change & Do & D4 & $\%$ change & Do & D4 & \% Change \\
\hline AFI00 & $37.22 \pm 0.08$ & $36.84 \pm 0.12$ & $-1.02^{\mathrm{a} * * *}$ & $25.78 \pm 1.07$ & $22.40 \pm 1.27$ & $-13.11^{\mathrm{b} * *}$ & $53 \pm 0.70$ & $48.4 \pm 1.07$ & -8.67 \\
\hline AF200 & $37.52 \pm 0.23$ & $37.18 \pm 0.18$ & $-0.90^{\mathrm{a} * * *}$ & $27.46 \pm 1.55$ & $24.46 \pm 1.76$ & $-10.92^{\mathrm{b} * *}$ & $50.6 \pm 1.16$ & $47.6 \pm 0.67$ & $-5.92^{\mathrm{a} * *}$ \\
\hline AF400 & $37.48 \pm 0.08$ & $37.42 \pm 0.07$ & $-0.16^{\mathrm{a} * * *}$ & $26.54 \pm 1.27$ & $23.9 \pm 1.49$ & $-9.94^{\mathrm{b} * *}$ & $52.6 \pm 0.40$ & $49.6 \pm 0.67$ & $-5.7^{a * * *}$ \\
\hline EFI00 & $37.06 \pm 0.12$ & $35.90 \pm 0.17$ & -3.13 & $27.56 \pm 1.16$ & $24.38 \pm 1.13$ & $-11.53^{\mathrm{b} * *}$ & $51.6 \pm 0.51$ & $46.8 \pm 0.66$ & -9.3 \\
\hline EF200 & $37.42 \pm 0.10$ & $36.62 \pm 0.24$ & $-2.13^{\mathrm{a} *}$ & $25.42 \pm 0.98$ & $23.26 \pm 0.81$ & $-8.49^{b} *$ & $52.6 \pm 0.40$ & $47.8 \pm 0.58$ & -9.12 \\
\hline EF400 & $37.14 \pm 0.10$ & $36.72 \pm 0.19$ & $-1.13^{\mathrm{a} * *}$ & $27.20 \pm 1.06$ & $24.80 \pm 1.39$ & $-8.82^{b *}$ & $51.4 \pm 0.67$ & $47.2 \pm 0.51$ & -8.17 \\
\hline CFI00 & $37.3 \pm 0.16$ & $36.70 \pm 0.15$ & $-1.60^{\mathrm{a} * *}$ & $28.06 \pm|.4|$ & $24.92 \pm 1.49$ & $-11.19^{\mathrm{b} * * *}$ & $51.4 \pm 0.67$ & $47.4 \pm 0.58$ & -7.78 \\
\hline CF200 & $37.82 \pm 0.09$ & $37.06 \pm 0.13$ & $-2.02^{\mathrm{a} * *}$ & $27.66 \pm 1.20$ & $25.00 \pm 1.14$ & $-9.59^{\mathrm{b} * *}$ & $51.4 \pm 0.67$ & $47.2 \pm 0.89$ & -8.17 \\
\hline CF400 & $37.5 \pm 0.07$ & $37.06 \pm 0.12$ & $-1.17^{a * *}$ & $27.72 \pm 1.24$ & $25.74 \pm 1.16$ & $-7.14^{\mathrm{a} *}, \mathrm{~b} *$ & $50.4 \pm 0.67$ & $48 \pm 1.07$ & $-4.76^{\mathrm{a}} * *$ \\
\hline $2 \% \mathrm{~T} 80$ & $37.76 \pm 0.23$ & $36.12 \pm 0.30$ & -4.34 & $29.38 \pm 0.91$ & $25.04 \pm 0.99$ & -14.77 & $50.8 \pm 0.86$ & $44.2 \pm 0.67$ & -12.99 \\
\hline CQ & $37.08 \pm 0.22$ & $36.94 \pm 0.16$ & $-0.37^{a * * *}$ & $26.66 \pm 1.34$ & $26.56 \pm 1.34$ & $-0.37^{\mathrm{a} * *}$ & $50.4 \pm 0.67$ & $48.6 \pm 0.67$ & $-3.41^{\mathrm{a} * * *}$ \\
\hline
\end{tabular}

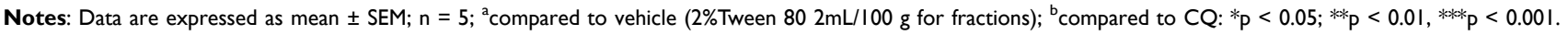
Numbers refer to dose in $\mathrm{mg} / \mathrm{kg}$.

Abbreviations: D0, pre-treatment value on day 0; D4, post treatment value on day four; CF, chloroform fraction; CQ, chloroquine; EF, ethyl acetate fraction; $A F$, aqueous fraction.

the aqueous fraction showed a significant effect in preventing PCV ( $p<0.05$ for both doses); but the effect was lower than the standard drug chloroquine $25 \mathrm{mg} / \mathrm{kg}(\mathrm{p}<0.001)$. On the other hand, 100 and $200 \mathrm{mg} / \mathrm{kg}$ of the chloroform fraction, $100 \mathrm{mg} / \mathrm{kg}$ aqueous fraction and all doses of the ethyl acetate fraction failed to prevent the reduction in packed cell volume significantly (Table 2).

\section{Curative Test of the Aqueous Fraction}

The fraction with the highest antimalarial activity (aqueous fraction) in the four-day suppressive test was further evaluated for its effect on established parasite infection. In this case, only $400 \mathrm{mg} / \mathrm{kg}$ of the aqueous fraction exhibited a statistically significant parasite level reduction $(\mathrm{p}<0.01)$ as compared to vehicle-treated mice. On the other hand, chloroquine $25 \mathrm{mg} / \mathrm{kg}$ cured all mice on day 7 and the reduction in parasitemia was significantly higher $(p<0.001)$ when compared to vehicletreated mice as well as all doses of the fraction. Only $400 \mathrm{mg} / \mathrm{kg}$ of the aqueous fraction significantly prolonged the survival time of mice compared to vehicle-treated mice $(\mathrm{p}<0.05)$ (Table 3).

Effect of the Aqueous Fraction on the Body Weight, Rectal Temperature and PCV

In this case, only $400 \mathrm{mg} / \mathrm{kg}$ of the aqueous fraction significantly prevented the reduction in the temperature compared to 
Table 3 Parasitaemia and Survival Time of Infected Animals Treated with an Aqueous Fraction of $P$. linearifolia in the Rane's Test

\begin{tabular}{|l|l|l|l|l|l|l|l|}
\hline \multirow{2}{*}{ Dose } & \multicolumn{5}{|c|}{ Parasitemia Level/Number of Parasitized RBCs } & \multirow{2}{*}{ \% Suppression } & \multirow{2}{*}{ Survival Time/Days } \\
\cline { 2 - 6 } & Day 3 & Day 4 & Day 5 & Day 6 & Day 7 & \\
\hline AF100 & $11.26 \pm 1.62$ & $25.30 \pm 4.16$ & $39.66 \pm 3.78$ & $53.36 \pm 2.60$ & $69.93 \pm 2.70^{\mathrm{b} * * *}$ & 11.18 & $9.00 \pm 0.70^{\mathrm{b} * * *}$ \\
AF200 & $9.01 \pm 1.49$ & $26.28 \pm 3.87$ & $40.42 \pm 2.47$ & $55.12 \pm 2.39$ & $69.84 \pm 2.05^{\mathrm{b} * * *}$ & 11.30 & $9.60 \pm 0.81^{\mathrm{b} * * *}$ \\
AF400 & $8.87 \pm 1.92$ & $12.47 \pm 3.24$ & $21.92 \pm 6.79$ & $27.14 \pm 9.16$ & $39.86 \pm 11.62^{\mathrm{a} * *}, \mathrm{~b} * *$ & 49.37 & $12.00 \pm 1.51^{\mathrm{a} * \mathrm{~b} * * *}$ \\
CON. & $11.52 \pm 1.86$ & $37.39 \pm 5.74$ & $61.62 \pm 6.87$ & $66.96 \pm 5.70$ & $78.75 \pm 5.60$ & - & $7.60 \pm 0.24$ \\
CQ25 & $9.56 \pm 3.04$ & $9.41 \pm 3.71$ & $1.10 \pm 0.40$ & $0.32 \pm 0.23$ & $0.00 \pm 0.00^{\mathrm{a} * * *}$ & 100.00 & $30.00 \pm 0.00^{\mathrm{a} * * *}$ \\
\hline
\end{tabular}

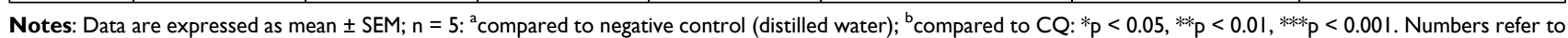
dose in $\mathrm{mg} / \mathrm{kg}$.

Abbreviations: $\mathrm{AF}$, aqueous fraction; $\mathrm{CQ}$, chloroquine; $\mathrm{CON}$, negative control.

vehicle-treated mice $(\mathrm{p}<0.05)$. However, its effect was much lower than chloroquine $25 \mathrm{mg} / \mathrm{kg}(\mathrm{p}<0.001)$. Chloroquine $25 \mathrm{mg} / \mathrm{kg}$ halted temperature dropping significantly compared to all doses of the fraction $(\mathrm{p}<0.05)$. Only $400 \mathrm{mg} / \mathrm{kg}$ of the aqueous fraction prevented body weight loss significantly as compared to vehicle-treated mice $(\mathrm{p}<0.05)$. The other doses of the fraction failed to attenuate body weight reduction significantly (Table 4).

Analysis of rectal temperature change of mice within groups showed that all doses of the aqueous fraction failed to prevent a significant rectal temperature change after treatment. Only the standard drug chloroquine $25 \mathrm{mg} / \mathrm{kg}$ averted significant rectal temperature reduction. Also, mice administered $400 \mathrm{mg} / \mathrm{kg}$ of the aqueous fraction did not show any significant weight change after treatment (Table 4).

All doses of the aqueous fraction failed to prevent PCV reduction significantly. However, the standard drug chloroquine $25 \mathrm{mg} / \mathrm{kg}$ averted $\mathrm{PCV}$ reduction significantly as compared to vehicle-treated mice $(\mathrm{p}<0.01)$ (Table 4$)$.

\section{Discussion}

The results indicated that the percentage parasitemia measured in the 4-day suppressive test was reduced dose-dependently by the solvent fractions in $P$. berghei infected mice, indicating the plant is endowed with antimalarial activity. Alkaloids and terpenoids present in the extract ${ }^{10}$ might be responsible for their antimalarial activity. The alkaloids are known to possess antiplasmodial properties, the most famous being quinine. ${ }^{19}$ Methanolic and chloroform extract of P. linearifolia is reported to possess in vitro antiplasmodial activity. ${ }^{9}$ Therefore, the present in vivo study on the solvent fractions is consistent with the previous in vitro findings and the in vivo test performed on the hydromethanolic extract of $P$. linearifolia. ${ }^{9,10}$

Among the fractions, the aqueous fraction was found to possess higher antimalarial activity than the chloroform and ethyl acetate fractions. Aqueous fractions are closer in composition to the aqueous preparations commonly used by traditional practitioners. Moreover, Francois et al have similarly investigated the organic extracts from the roots, stem bark, fruit rind, seeds, and leaves of plants and found a wide range of activities with the highest activities being found in the methylene chloride root extracts. ${ }^{20}$ Therefore, the present in vivo study is consistent with the previous in vitro findings.

So many chemical compounds have been isolated and identified from species of the Periploca genus, such as $\alpha$ and $\beta$-amyrin, lupeol, and $\beta$-sitosterol from Periploca

Table 4 Bodyweight, Rectal Temperature, and Packed Cell Volume (PCV) Change of Infected Mice Treated with an Aqueous Fraction of $P$. linearifolia in the Rane's Test

\begin{tabular}{|l|l|l|l|l|l|l|l|l|l|}
\hline \multirow{2}{*}{ Dose } & \multicolumn{2}{|l}{ Weight/Gram } & \multicolumn{2}{l|}{ Temperature ${ }^{\circ} \mathbf{C}$} & \multicolumn{2}{c|}{ PCV } \\
\cline { 2 - 10 } & D0 & D4 & $\%$ Change & D0 & D4 & $\%$ Change & D0 & D4 & $\%$ Change \\
\hline AF100 & $27.98 \pm 0.95$ & $26.32 \pm 1.10$ & -5.93 & $37.62 \pm 0.13$ & $33.40 \pm 0.14$ & $-11.21^{\mathrm{b} * * *}$ & $49.4 \pm 0.67$ & $40 \pm 1.51$ & -19.02 \\
AF200 & $28.16 \pm 1.84$ & $26.38 \pm 1.60$ & -6.32 & $37.18 \pm 0.26$ & $34.20 \pm 0.35$ & $-8.01^{\mathrm{b} * *}$ & $48.8 \pm 0.66$ & $39.4 \pm 1.20$ & -19.26 \\
AF400 & $29.12 \pm 0.99$ & $28.24 \pm 1.36$ & $-3.02^{\mathrm{a} *}$ & $37.86 \pm 0.14$ & $35.94 \pm 0.47$ & $-5.07^{\mathrm{a} * \mathrm{c} * *}$ & $47.8 \pm 1.11$ & $40.8 \pm 1.24$ & -14.64 \\
2\%T80 & $27.26 \pm 1.13$ & $23.64 \pm 1.27$ & -13.27 & $36.74 \pm 0.21$ & $32.44 \pm 0.20$ & -11.70 & $49.8 \pm 0.86$ & $37.2 \pm 0.73$ & -25.3 \\
CQ25 & $26.08 \pm 1.20$ & $26.56 \pm 1.39$ & $1.9^{\mathrm{a} * *}$ & $36.64 \pm 0.17$ & $36.22 \pm 0.24$ & $-1.14^{\mathrm{a} * * *}$ & $47.4 \pm 0.92$ & $44.4 \pm 0.87$ & $-6.32^{\mathrm{a} * *}$ \\
\hline
\end{tabular}

Notes: Data are expressed as mean $\pm \mathrm{SEM} ; \mathrm{n}=5$ : $^{\mathrm{a}}$ compared to $2 \% \mathrm{~T} 80 ;{ }^{\mathrm{b}}$ compared to CQ; ${ }^{\mathrm{c}}$ compared to AFI00: ${ }^{*} \mathrm{p}<0.05$, **p $<0.01$, *** $\mathrm{p}<0.00 \mathrm{I}$. Numbers refer to dose in $\mathrm{mg} / \mathrm{kg}$.

Abbreviations: D0, pre-treatment value on day 0; D4, post-treatment value on day four; AF, aqueous fraction; CQ, chloroquine. 
laevigata. ${ }^{21}$ Moreover, several lupene-type triterpenes and elemane-type sesquiterpenes have been isolated from Periploca aphylla and roots of $P$. laevigata respectively. ${ }^{21,22}$ Lupeol, $\beta$-amyrin, and $\beta$-sitosterol (terpenoids) inhibited both chloroquine-sensitive and resistant strains of $P$. falciparum in in vitro studies. ${ }^{23}$ Therefore, the antiplasmodial activity of $P$. linearifolia in the present in vivo study is in agreement with other plants belonging to the same sub-family and genus.

Anemia, bodyweight loss, and body temperature reduction are the general features of malaria-infected mice. ${ }^{24}$ PCV was measured to evaluate the effectiveness of the solvent fractions in preventing hemolysis due to escalating parasitemia levels. The underlying cause of anemia includes the following mechanisms; the clearance and/or destruction of infected RBCs, the clearance of uninfected RBCs, and erythropoietic suppression and dyserythropoiesis. Each of these mechanisms has been implicated in both human and rodent malarial anemia. ${ }^{25}$ This necessitates hematocrit (PCV) analysis that evaluates the effectiveness of the extract in preventing hemolysis. In the four-day suppressive test 200 and $400 \mathrm{mg} / \mathrm{kg}$ of the aqueous and $400 \mathrm{mg} / \mathrm{kg}$ of the chloroform fractions prevented PCV reduction significantly. This reversal of PCV reduction by the solvent fractions may be related to parasitemia level reduction with the fractions.

All the doses of the fractions, except $400 \mathrm{mg} / \mathrm{kg}$ of chloroform fraction, failed to prevent the reduction in body weight significantly. This phenomenon in decrement of body weight may be due to disturbed metabolic function and hypoglycemia that has been reported to be associated with malaria infection. ${ }^{26}$ Rectal temperature measurement showed that the mice developed hypothermia particularly in the late infection (Rane's test) with P. berghei parasites. Fever is one of the symptoms of human malaria. In contrast, this model of malaria was associated with hypothermia rather than pyrexia. In the curative test, the infected mice developed profound hypothermia with a rectal temperature falling by as much as $5^{\circ} \mathrm{C}$. The prolonged development of hypothermia in mice can be attributed to the general debilitating effects of malaria on the host, which results in the loss of body heat and eventual death. The absence of pyrogenic response in this model is that small animals like mice have a large surface area-to-body mass ratio, which resulted in a higher degree of heat loss and prevents the development of fever caused by pyrogenic agents. ${ }^{27}$ Malaria parasites also affect host carbohydrate, lipid, and protein metabolism. ${ }^{28,29} \mathrm{~A}$ decrease in the metabolic rate of infected mice occurred just before death and was accompanied by a corresponding decrease in internal body temperature. ${ }^{30}$ Therefore, effective antimalarial agents are expected to prevent the reduction in rectal temperature. As a result, the aqueous fraction was able to significantly prevent the reduction in rectal temperature as compared to vehicletreated mice.

In the curative test, blood samples were taken and smears were prepared daily to evaluate the curative ability of the solvent fractions. As indicated in the results section, $400 \mathrm{mg} / \mathrm{kg}$ of the aqueous fraction brought about a reduction of parasitemia level after the first dose as the standard drug chloroquine $25 \mathrm{mg} / \mathrm{kg}$. Generally, the results obtained from the curative test suggest that $400 \mathrm{mg} / \mathrm{kg}$ of the aqueous fraction has therapeutic efficacy against the established malaria parasite.

Anti-malarial test materials with more than 30\% suppressive effect on the level of parasitemia ${ }^{31,32}$ compared to the negative control group are often considered effective in standard screening tests. Therefore, the present in vivo antimalarial activity test of the solvent fractions denotes $P$. linearifolia is effective in both the four-day suppressive test and curative test models. Therefore, the previous in vitro ${ }^{9}$ and crude (hydromethanolic) extract in vivo studies ${ }^{10}$ and the current studies of chloroform, ethyl acetate, and aqueous fractions in vivo studies confirm that the plant $P$. linearifolia contains active antimalarial compounds.

\section{Conclusion}

The present study indicated that aqueous and chloroform fractions of $P$. linearifolia have a promising antiplasmodial activity, with varying degrees on the measured parameters. The findings of this study are consistent with the traditional use and the earlier in vitro and hydromethanolic in vivo findings.

\section{Recommendation}

Further research should be conducted to determine subacute and chronic toxicity studies in higher animals to know the safety of $P$. linearifolia. The authors recommend the purification of the plant material to get lead antimalarial compounds. Moreover, safety and efficacy have to be studied in detail in higher laboratory animals before it proceeds to clinical trial.

\section{Abbreviations}

ANOVA, Analysis of Variance; MST, Mean Survival Time; OECD, Organization for Economic Cooperation and Development; PCV, Packed Cell Volume; SPSS, Statistical 
Packages for Social Science; WHO, World Health Organization.

\section{Data Sharing Statement}

All the data obtained from the experiment was recorded first in the paper. Finally, it was entered in SPSS software and analyzed using one-way ANOVA. The results are listed in tables in the manuscript. Also, standardized materials were used.

\section{Ethics Approval}

The study protocol was approved by the ethical review board of the department of pharmacology, school of pharmacy, University of Gondar (ethical approval number, SOP4/75/09). Moreover, all protocols were performed based on the International Animal Care and Welfare Guidelines (the OECD guidelines for testing of chemicals).

\section{Acknowledgments}

This paper entitled "Antimalarial activity of solvent fractions of the stem bark of Periploca linearifolia Quart.-Dill. \& A.Rich. (Asclepiadaceae) against Plasmodium berghei in mice" is based on the thesis "Antimalarial activity of crude extract and solvent fractions of the stem bark of Periploca linearifolia Quart.-Dill. \& A.Rich. (Asclepiadaceae) against Plasmodium berghei in mice" written by Wubetu Yihunie Belay, Abyot Endale Gurmu, Zewdu Birhanu Wubneh. The authors would like to thank Mr. Kassie Genet (a traditional healer at Tikil Dingay town, North Gondar, Ethiopia) for his unreserved support during plant material collection. Ethiopian Public Health Institute, Addis Ababa, is also greatly acknowledged for providing malaria parasites and mice.

\section{Author Contributions}

All authors made a significant contribution to the work reported, whether that is in the conception, study design, execution, acquisition of data, analysis, and interpretation, or in all these areas; took part in drafting, revising, or critically reviewing the article; gave final approval of the version to be published; have agreed on the journal to which the article has been submitted, and agreed to be accountable for all aspects of the work.

\section{Funding}

The Traditional Medicine Research Project, University of Gondar (Under the mega project with a reference number of $\mathrm{VP} / \mathrm{RCS} / 05 / 445 / 2015)$ assisted us in material, reagent $\&$ chemical supply, and covering of some costs for carrying out the research. In addition, The Amhara Regional Health Bureau supported us financially.

\section{Disclosure}

The authors declare that they have no competing interests.

\section{References}

1. World Health Organization. World malaria report 2020: 20 years of global progress and challenges. In: World Malaria Report 2020: 20 Years of Global Progress and Challenges. World Health Organization; 2020.

2. Gething PW, Elyazar IR, Moyes CL, et al. A Long neglected world malaria map: Plasmodium vivax endemicity in 2010. PLoS Neglect Trop Dis. 2012;6:e1814. doi:10.1371/journal.pntd.0001814

3. Snow RW, Omumbo JA, Lowe B, et al. Malaria. In: Jamison DT, Feachem RG, Makgoba MW, editors. Disease and Mortality in SubSaharan Africa. 2nd ed. Washington (DC): The International Bank for Reconstruction and Development/The World Bank; 2006.

4. World Health Organization. Guidelines for the Treatment of Malaria. 3rd ed. World Health Organization; 2015.

5. Institute of Medicine (US). Committee on the economics of antimalarial drugs. In: Arrow KJ, Panosian C, Gelband H, editors. Saving Lives, Buying Time: Economics of Malaria Drugs in an Age of Resistance. National Academies Press (US); 2004.

6. World Health Organization. WHO recommends groundbreaking malaria vaccine for children at risk. Historic RTS, S/AS01 recommendation can reinvigorate the fight against malaria; 2021. Available from: https://www. who.int/news/item/06-10-2021-who-recommends-groundbreakingmalaria-vaccine-for-children-at-risk. Accessed December 22, 2021.

7. Schmelzer GH. Periploca linearifolia Quart.-Dill \& A. Rich. In: Schmelzer GH \& Gurib-Faki A, Eds. Plant Resources of Tropical Africa 11(2). Medicinal Plants 2. PROTA Foundation, Wageningen, Netherlands / CTA, Wageningen, Netherlands: 2013;202-204. Available from: https://www.google.com.et/books?id= 3clmAgAAQBAJ\&pg. Accessed December 29, 2021

8. Muthaura CN, Rukunga GM, Chhabra SC, Mungai GM, Njagi ENM. Traditional phytotherapy of some remedies used in the treatment of malaria in Meru district of Kenya. S African J Botany. 2007;73 (3):402-411. doi:10.1016/j.sajb.2007.03.004

9. Ayuko TA, Njau RN, Cornelius W, Leah N, Ndiege IO. In vitro antiplasmodial activity and toxicity assessment of plant extracts used in traditional malaria therapy in the Lake Victoria Region. Memórias Do Instituto Oswaldo Cruz. 2009;104:689-694. doi:10.1590/S0074-02762009000500004

10. Belay WY, Gurmu AE, Wubneh ZB. Antimalarial activity of stem bark of periploca linearifolia during early and established plasmodium infection in mice. Evid Based Complement Altern Med. 2018;2018:1-7. doi:10.1155/2018/4169397

11. Musoke F. Natural products, with antimalarial activity phytochemistry and pharmacognosy. Encyclopedia of Life Support Systems. 2016.

12. Chemical studies on qinghaosu (artemisinine). China Cooperative Research Group on qinghaosu and its derivatives as antimalarials. $J$ Tradit Chin Med. 1982;2(1):3-8.

13. OECD. Test No. 425: Acute Oral Toxicity: Up-And-Down Procedure, OECD Guidelines for the Testing of Chemicals, Section 4. Paris: OECD Publishing; 2008.

14. Waako PJ, Gumede B, Smith P, Folb PI. The in vitro and in vivo antimalarial activity of Cardiospermum halicacabum L. and Momordica foetida Schumch. Et Thonn. J Ethnopharmacol. 2005;99(1):137-143. doi:10.1016/j.jep.2005.02.017 
15. Desta B. Ethiopian traditional herbal drugs. Part II: antimicrobial activity of 63 medicinal plants. $J$ Ethnopharmacol. 1993;39 (2):129-139. doi:10.1016/0378-8741(93)90028-4

16. Fidock DA, Rosenthal PJ, Croft SL, Brun R, Nwaka S. Antimalarial drug discovery: efficacy models for compound screening. Nat Rev Drug Discov. 2004;3(6):509-520. doi:10.1038/nrd1416

17. Kalra BS, Chawla S, Gupta P, Valecha N. Screening of antimalarial drugs: an overview. Indian J Pharmacol. 2021;38:5-12. doi:10.4103/ 0253-7613.19846

18. Ryley JF, Peters W. The antimalarial activity of some quinolone esters. Ann Trop Med Parasitol. 1970;64(2):209-222. doi:10.1080/ 00034983.1970 .11686683

19. Saxena S, Pant N, Jain DC, Bhakuni RS. Antimalarial agents from plant sources. Curr Sci. 2003;85:1314-1329.

20. François G, AkéAssi L, Holenz J, Bringmann G. Constituents of Picralima nitida display pronounced inhibitory activities against asexual erythrocytic forms of Plasmodium falciparum in vitro. $J \quad$ Ethnopharmacol. 1996;54(2-3):113-117. doi:10.1016/S03788741(96)01456-0

21. Askri M, Mighri Z, Bui AM, Das BC, Hylands PJ. Medicinal plants of Tunisia. The structure of periplocadiol, a new elemane-type sesquiterpene isolated from the roots of Periploca laevigata. J Nat Prod. 1989;52(4):792-796. doi:10.1021/np50064a021

22. Mustafa G, Anis E, Ahmed S, et al. Lupene-type triterpenes from Periploca a phylla. J Nat Prod. 2000;63(6):881-883. doi:10.1021/ np990426v

23. Nyangasi L. Characterisation of antimalarial compounds from plants used in traditional health practices in Lake Victoria basin (Doctoral dissertation). 2014.

24. Langhorne J, Quin SJ, Sanni LA. Mouse models of blood-stage malaria infections: immune responses and cytokines involved in protection and pathology. Chem Immunol. 2002;80(80):204-228.
25. Chinchilla M, Guerrero OM, Abarca G, Barrios M, Castro O. An in vivo model to study the anti-malaric capacity of plant extracts. Revista de Biología Trop. 1998;46(1):35-39.

26. World Health Organization. World Malaria Report: 2012. World Health Organization; 2012.

27. Jennings G, Elia M. Effect of E. coli endotoxin on temperature, oxygen consumption and brown adipose tissue thermogenesis in rats and mice. Biosci Rep. 1987;7(6):517-523. doi:10.1007/ BF01116509

28. Siddiqui WA, Trager W. Free amino acids of blood plasma and erythrocytes of normal ducks and ducks infected with a malarial parasite, plasmodium lophurae. Nature. 1967;214(5092):1046-1047. doi:10.1038/2141046a0

29. Angus MGN, Fletcher KA, Maegraith BG. Studies on the lipids of Plasmodium knowlesi-infected rhesus monkeys (Macaca mulatta). Ann Trop Med Parasitol. 1971;65(2):135-154. doi:10.1080/ 00034983.1971.11686740

30. Hansen BD, Pappas PW. Brief note acute malaria: effects of plasmodium berghei on the metabolic rate of mice. 1977.

31. Silva J, Ramos A, Machado M, et al. A review of antimalarial plants used in traditional medicine in communities in Portuguese-speaking countries: Brazil, Mozambique, Cape Verde, Guinea-Bissau, São Tomé and Príncipe and Angola. Memórias Do Instituto Oswaldo Cruz. 2011;106(Suppl 1):142-158. doi:10.1590/S007402762011000900019

32. Adugna M, Feyera T, Taddese W, Admasu P. In vivo antimalarial activity of crude extract of aerial part of Artemisia abyssinica against Plasmodium berghei in mice. Globl J Pharmacol. 2014;94:199-206. doi:10.1159/000368559

\section{Publish your work in this journal}

The Journal of Experimental Pharmacology is an international, peerreviewed, open access journal publishing original research, reports, reviews and commentaries on all areas of laboratory and experimental pharmacology. The manuscript management system is completely online and includes a very quick and fair peer-review system. Visit http://www.dovepress.com/testimonials.php to read real quotes from published authors.

Submit your manuscript here: https://www.dovepress.com/journal-of-experimental-pharmacology-journal 